\title{
REFLEXÕES SOBRE O PAGAMENTO POR SERVIÇOS AMBIENTAIS E AS PERPSEPCTIVAS SOBRE PSAs NO BRASIL
}

\author{
REFLECTIONS ON PAYMENT FOR ECOSYSTEM \\ SERVICES AND PES PERSPECTIVES IN BRAZIL \\ REFLEXIONES SOBRE EL PAGO DE SERVICIOS \\ AMBIENTALES Y EN PERPSEPCTIVAS PSA EN BRASIL
}

\section{Andre Geraldo Berezuk}

Doutorado em Geografia pela Universidade Estadual Paulista Júlio de Mesquita Filho. Docente no Programa de Pós-graduação em Geografia da Universidade Federal da Grande Dourados (UFGD). Universidade Federal da Grande Dourados, Faculdade de Ciências Humanas, Rodovia DouradosItahum, km12, Cidade Universitária. 79825-070 - Dourados-MS

E.mail:andrebzk713@bol.com.br

\section{Antonio Augusto Rossotto loris}

Human Geography Lecturer. Institute of Geography, School of Geosciences. University of Edinburgh - Scotland. Institute of Geography - School of Geosciences. The King's Buildings. James Hutton Road. Edinburgh. EH9 3FE

E.mail:a.ioris@ed.ac.uk

\begin{abstract}
The global discussion about environmental issues claims for more effective and innovative actions which give more credit to a better ratio between Nature and Humankind. For developing this type of relationship, it is important to think, discuss and plan new strategies of environmental planning such as the Payment for Ecosystems Services (PES) schemes. The justification for these programs is that the conservation proceedings require better approaches that foster the conciliation between economic development, social development, preservation and conservation of their natural areas. Moreover, PES could allow more time to review their own concepts about environment ethical values, in special about a market system that explores much more than the planet can regenerate. Following this goal, the aim of this paper is to discuss the importance of PES for environmental policies and to examine the perspective of PES utilization in Brazil on a macro-scale scope.
\end{abstract}

Keywords: payment for ecosystems services; economical-environmental strategies; Brazil. 


\section{RESUMO}

O debate global sobre a questão ambiental clama por mais efetivas e inovadoras ações que possam oferecer maior credibilidade e uma melhor compreensão da relação Humanidade e Natureza. Para o desenvolvimento desta relação, é importante pensar e elaborar novas estratégias de planejamento ambiental, tal como programas de Pagamento por Serviços Ambientais (PSAs). A justificativa para estes programas é de que os procedimentos vinculados à conservação requerem um melhor aperfeiçoamento, para que seja reforçada a conciliação entre desenvolvimento econômico, desenvolvimento social, preservação e conservação das áreas naturais. No mais, os PSAs podem permitir um maior ganho de tempo para que a Sociedade possa rever seus conceitos vinculados aos valores éticos ambientais, especialmente quando relacionados à questão do sistema de mercado que explora muito mais do que o planeta consegue recompor. Seguindo este objetivo, o ponto central deste artigo é discutir sobre a importância dos PSAs no âmbito das políticas ambientais e examinar a perspectiva da aplicação destes PSAs no Brasil em um escopo macroescalar.

Palavras-chave: pagamento por serviços ambientais; estratégias econômico-ambientais; Brasil.

\section{RESUMEN}

La discusión global sobre la cuestión del medio ambiente clama por más efectivas y innovadoras acciones que puedan desarrollar una mayor credibilidad y una mejor comprensión de la dialéctica Humanidad y Naturaleza. Para empezar un desarrollo de esta dialéctica, es importante pensar y preparar nuevas estrategias de planeamiento ambiental, tal como los programas de Pago por Servicios Ambientales (PSAs). La justificación de estos programas es que los procedimientos vinculados a la conservación necesitan un mejor perfeccionamiento, para que sea fortalecida la conciliación entre desarrollo económico, desarrollo social, preservación y conservación de las áreas naturais. Además, los PSAs pueden permitir un mayor tiempo disponible para que la Sociedad pueda volver sus conceptos vinculados a los valores éticos ambientales, de modo especial cuando eses están vinculados a la cuestión de lo sistema de mercado que explora mucho más do que la Tierra consigue recomponer. Mirando este objetivo, el ponto central de este artigo es discutir sobre la importancia de los PSAs en el ámbito de las políticas ambientales y examinar la perspectiva de la aplicación de estos PSAs en Brasil en uno escoplo macroescalar.

Palabras-clave: pago por servicios ambientales; estrategias económico-ambientales; Brasil. 


\section{INTRODUCTION}

Seeking for new environmental management methods is a shared target point for any society which is eager to find equitable and effective solutions for environmental problems and impacts. In Brazil it is not different. However, the development of innovative approaches, such as payment for ecosystem services, is not an ordinary work, but constitutes a complex activity which puts at the same level economic, social and political challenges. Thus, the aim of this work is to analyze PES issues within two main aspects:

1. a theoretical aspect - conceptualizing PES epistemological concepts, to understand PES as important tools toward the development of environmental policies;

2. a case study aspect - understanding how PES development actions could be strategic for a country (Brazil), thinking how PES could be inserted into Brazilian Environmental Policy scope within a macro scale (national scale).

When we think about these two aims, our focus is:

1. to increase PES importance as a strategic environmental policy tool, in spite of many academic critical views about PES;

2. to give a contribution to Brazil about its PES environmental policy development process.

The discussion of the Payment for Ecosystem Services (or Environmental Services) (PES) in Brazil is relatively recent and has been on the agenda for only the last ten years. The aim is to find alternatives that could contribute to a new technical methodology inside the scope of the Brazilian environmental policies. The process of Payment for Ecosystem Services is more properly conceptualized as a type of market-like tool, that could bring profits to the efforts of conserving forest areas and to foster production under agroecology principles. Agustsson et. al. (2014) state that:

even though PES programmes are not designed to produce poverty reduction and economic development, they are expected to have the potential to contribute to this by conserving the natural ecosystems on which rural poor depend, and by providing additional income through payments.

Some authors, as Brown et. al. (2011) or Brazier et. al. (2012), did not research about PES directly, but have drawn a positive perspective of PES potential evolution with 
the developing concepts of rewildering ${ }^{1}$ and geodiversity ${ }^{2}$. Agoramoorthy et. al. (2012) and Fisher et. al. (2014) hold a clearer and more direct point of view about PES social importance, claiming that PES is a real tool for the alleviation of poverty. The use of PES by the government sectors are being adopted for political land-use rules and for the policies of conserving and preserving natural areas inside the territories (Eloy et. al. 2013). Reflecting on the current concept of PES, we quote a classical PES explanation given by Wunder (2005), who classifies PES as a new paradigm of conservation:

Payments for environmental services (PES) are part of a new and more direct conservation paradigm, explicitly recognizing the need to bridge the interests of landowners and outsiders. Eloquent theoretical assessments have praised the absolute advantages of PES over traditional conservation approaches (WUNDER, 2005, p.1).

Furthermore, there is a very didactic and clear point of view about PES by Van Hacken et. al. (2015). They claim that PES are a main tool for solving failures of conventional market system and they are deeply linked between ecological, social-political and economic contexts. Thus, these researchers show a classical and a Malthusian context of a rising Humankind that needs higher demands of primary resources but is destroying these same resources at same time.

It has taken Brazil a relatively long historic period for the consolidation of its environmental policies in order to achieve this new stage of policy development. The evolution of the Brazilian Environmental Policies could be divided into three sub periods: 1) a pre-industrialization and liberal economic period (1900 - 1930);2) a strengthening period of State policies (1930-1980); 3) an economic neoliberalization period (after 1990 until nowadays). These three sub-periods represent the different phases of water development policies through the twentieth century until nowadays (Ioris, 2006). Similarly, Neder (2002) defines the historical implementation of environmental policies in Brazil, which separates a nationalist period from 1930 to 1980 (which corresponds to the industrialization period of Brazil) and the phase after the Brazilian Constitution of 1988 (from the economic neoliberalization period until nowadays).

\footnotetext{
Concept of Rewildering - Quoting Brown et. al. (2011) "Rewilding is a strategy for the conservation of complete, self-sustaining ecosystems, primarily involving the protection and, where necessary, reintroduction, of populations of keystone species in large, connected reserve networks".

2 Geodiversity - Quoting Hansom (2012), "Understanding geodiversity is therefore a key requirement in a more sustainable future. It provides the essential under- pinnings of the natural environment and thus is fundamental to the support of all biodiversity functions, landscapes, habitats and species. Geodiversity also has direct relevance to economic activities and cultural heritage, as well as to mitigation of the impact of climate change. It delivers ecosystem services in both rural and urban settings and provides the basis for truly sustainable management of the environment in the face of change".
} 
It is important to follow and discuss this historical structure about Brazilian Policies and PES concepts, to show the close and strong relationship between Brazilian Water Policies and Brazilian Environmental Policies, which is vital to understand this issue.

\section{OVERVIEW OF THE LEGAL AND INSTITUTIONAL EVOLUTION IN BRAZIL}

The development of a regime of payment for ecosystems services in Brazil will impact other areas of environmental conservation, especially in the context of the organization of new River Basin Committees (Brazil's equivalent of Regional Water Authority -RWA in Great Britain), which are very important institutions when we search for examples of payments for ecosystems services. These water committees were created in Brazil in 1997 by the scope of Brazil Water Act (BRAZIL, Law 9433/97). Nevertheless, older committees in Brazil were created in 1991, by the Brazilian State of Sao Paulo (Sao Paulo State, Law 7663/91), before the Law 9433.

In fact, the Brazil Water Act is, still nowadays, a strong bet of the Brazilian Government, despite serious barriers and difficulties for its comprehensive implementation. This act presents a bolder structure of Water Government mechanism, showing and searching for more complex political and technical instruments. The Brazil Water Act has represented a serious opportunity to change the excessive historic centralism of political water actions. Moreover, the Law 9433 states that water has an economic value and it is also a public element, which represents a clear ideological change if you compare with past Brazilian policies.

Notwithstanding the fact that the experts are almost unanimous, in Brazil, to claim that the Law 9433 has an unquestionable importance for all strategic sectors related to the development of the Brazilian territory, this act has shown partial results so far. These results could be more accurate if the technical scope of this policy was better developed. However, for the value of the technical sectors of programmes it is necessary to have investments that include the objective to train more qualified labour within the Brazilian federal institutions involved in water resources. The development of Brazilian Water Act is of fundamental importance for Brazil's own image in front of the world as well, importance which is represented by an extensive quantity of articles and researches (Canepa et. al. 1999; Luchini 2000; Setti et. al. 2001, Lanna et. al. 2002; HIDROWEB (www site); Veiga \& Magrini 2013, etc.). Nevertheless, the efforts to turn this water policy mechanism viable are a real challenge that overpasses the technical scope and has faced an antagonistic reaction from strong private interests (Ioris, 2010). 
Also, the Brazilian Water Act strengthens the Brazilian Environmental Act enforcement (Brazil, Law 6938/1981) and strengthens the enforcement of the Brazilian Constitution of 1988, respecting the principles of its article 225. The Law 6938 of 1981 is an old law with more than three decades of existence, however, it did not lose its importance throughout the years. The Brazilian Environmental Act has some gaps, anyway. These gaps are understandable if we consider the historic aspects of Brazil, when this country became a democracy in the 1980s. A first gap is the legalization of a large national environmental system without a planned structure related to the instruments of this quoted environmental system.

Another relevant problem with the Law 6938 is the fact that it does not make any reference about geographical scales into the Brazilian Environmental System. This sort of weakness became a problem of focus when related to its actions along the decades in Brazil. One example of strategic actions using geographical concepts only appeared with the creation of Ecological-Economic Zoning rules in 2002 (Brazil, Decree 4297/2002).

There is a third gap, which is not an exclusively Brazilian aspect, but it also occurs worldwide: policy systems need to be respectable and enforceable. Nevertheless, in order to make every policy or law respectable, there are two aspects that must be considered: the law must be understandable, with a clear technical and methodological level, and the Brazilian institutions and population must have a moral and ethical level to obey the laws.

Despite developing environmental policies structure and actions, the Brazilian national and state (provincial) governments have faced multiple difficulties to elaborate and adopt mechanisms to ensure the protection of the natural areas and the fragile ecosystems. To solve this problem, this country is searching for economic mechanisms to make the protection of forest areas more attractive. In fact, the search for methods to develop PES can be a very important way for protecting not only Brazilian natural areas. These methods would also bring new technical ideas for the world environmental issues.

\section{CRITICAL ASSESSMENT OF THE SYSTEMS OF PAYMENT INSIDE ENVIRONMENTAL SERVICES AND THE PERSPECTIVES OF PES IN BRAZIL}

PES began to appear in the 1990s worldwide, inside the scope of Environmental Policy Acts and Political studies. The increasing value of PES is related to the increase of the concept of sustainable development. The concept of sustainable development was presented by the Conference of United Nation for the Environment and Development in 1992 (Rio de Janeiro, Brazil), and PES became an important instrument to reach the sustainable development. Nevertheless, the origin of PES discussion appeared prior to that, in the 1980s in the United States, with the development of the concept of Ecosystem 
Services. The aim of the concept of Ecosystem Services is to give a monetary value for the ecosystems to stimulate its conservation (Eloy et. al., 2013).

Despite the fact that there are many private interests of inserting PES around the world, this instrument has an important role in policy-making, inside the political strategic sectors, including catchment committees and similar organizations. Thus, the national institutions have an essential role also for the development of the countries, because these institutions will allow the evolution and the consolidation of the national policy actions (Fukuyama, 2005). The strength of national institutions could develop the political systems of governance, with the development of their technical scope. In fact, the development of political systems of governance is going to offer conditions to the PES evolution and execution with an expected efficiency. Therefore, Brazil has been seeking to increase the power of influence of its environmental institutes since 1990s (e.g. Brazilian Environment Institute - IBAMA, established in 1989; Brazilian Water Agency - ANA, established in 2000; Chico Mendes Biodiversity Institute - ICMBio, established in 2007, among other environmental institutes). Nevertheless, despite this historical period of strengthening of these institutes (with the focus on their technical development), Brazil continues to show critical problems of know-how about its environmental actions. This situation could explain the unsatisfactory Brazilian development of political PES actions so far (which could show why Brazil still does not have a policy about PES) :

Following these concepts that are being presented about PES and about the development of Brazilian Environment Laws and Institutes, the Brazilian River Basin Committees (with collaboration of Brazilian Water Agency) started the discussion about first actions to create a payment system based on environmental services. These actions have to follow the rules of Brazilian Water Act. A major point about this subject has been about two aspects: how to create an environmental payment system that should be attractive for the land owner, for economic groups and especially for social groups that live in rural areas. Moreover, at the same time, it is also desired a system that would be practical to be used. We believe that an efficient environmental system can be created if these two factors are interconnected.

Environmental services are often thought with the principle of protector-receiver ${ }^{3}$, epistemological principle that is used together with polluter pays principle (PPP) ${ }^{4}$. The principle of protector-receiver, however, is preferred by countries and organizations.

3 Principle of Protector-receiver - principle that the person who is protecting the environment will benefit from that action.

4 Polluter pays principle (PPP) - principle that "Polluters should pay for their environmental damage (with certain exemptions to take into account the need to eliminate regional disparities". (Principle 5, First Environmental Action Programme, 1973), in Barnes \& Barnes (1999, p. 30). 
In Brazil, the more structured River Basin Committees have begun to think about plans considering the payment for ecosystems services within micro river basin areas as well as local areas. There are two major chosen aspects in Brazil regarding the process of elaboration of payment into Ecosystem Services:

1. the protection of green areas per hectare, searching the committee for a local and regional water protection;

2. the avoidance of high levels of erosion of soil by the land use of the property, which will help water protection as well.

These two main aspects were chosen by PCJ (Piracicaba-Capivari-Jundiai) Water Committee, in Sao Paulo State. This water committee, which is responsible for the surveillance of water quality for 40 or $45 \%$ of Sao Paulo Metropolitan Area (area which represents eight to ten millions potable water consumers), is a Brazilian leading group that develops studies of management actions in water payment systems in Brazil, and helps, technically, the Brazilian Water Governance. This River Basin Committee plans to pay the land owner or private groups who preserve or conserve forests areas, turning these areas into forest areas, especially the ones that are located near river or brooks. These areas are called, academically, riparian forests and have a great importance for the water protection actions. This action, proposed by this committee, can be converted into a Water Provider Program $^{5}$ (Programa Produtor de Água), which appears in the law project 5487 scope (PES project law), from $2009^{6}$.

Overall, PES could become an important tool of territorial planning actions and policies, which could develop the Brazilian environmental framework. Important researchers, as Becker, Ab'Saber, Fearnside and Lourenço (apud Clüsener-Godt \& Sachs 1995), highlight the importance of environmental planning projects in social-environment tasks within the Brazilian Territory. These authors propose strategic alternatives for a better and higher social-environment development, in special of the Amazon Region. PES are undoubtedly an important element to the increase of Territory Intelligence concept ${ }^{7}$.

\footnotetext{
5 The main goal of this program is to be a potential way to reduce erosion taxes and to protect the water quality in its river basin areas. This important environmental program is organized by ANA-Brazil. Through this program, the land owner who protects his water in his property will earn profits by this effort. This positive action brings not only local and individual profits for the land owner but also brings development and good results to all river basin drainage net. The major scope of action related with this program can be defined as: the brooks conservation, the consolidation of areas of permanent preservation, the consolidation of the areas of legal forest reserves; the protection of soils into the landscape, the repairing of local dirt roads, etc.

6 Brazil does not have an Environmental Services Payment Act yet, but there is a bill (Brazil bill 5487/2009) being discussed in the Brazilian Congress.

7 Quoting Bertacchini et. al. (2007): "L'intelligence territoriale, objet et champ scientifique, se pose à la convergence de l'information, de la communication et de la connaissance, traduit une relation Espace-territoire', succède à la territorialité, en tant que phénomène d'appropriation ou de réappropriation des ressources, enfin, permet lénoncé du projet territorial lorsque l'échelon territorial arrive à le formuler". Translation by the authors: "The Territory Intelligence is an object and field of the science which
} 


\section{VIEWS ON PES CONCEPTIONS AND IDEAS}

The proceedings about PES concepts are not simple, as they do not only constitute technical and economical actions but also represent a deep reflection on political actions. There are some positive but also some very negative points of view in relation to PES.

There are researches that emphasizes PES as a strategic tool for the macro-scale political actions of the territory. Following the idea of PES development (as a social-environment and territory development tool) we can quote Ab'Saber apud Clüsener-Godt \& Sachs (1995). $\mathrm{Ab}$ 'Saber values the theoretical and technical efforts for social-environment programs and projects which are going to contribute with the increase of Brazil's people quality of life. More than that, $\mathrm{Ab}^{\prime}$ 'Saber draws our attention to the unique technical knowledge of the riverine and indigenous groups for a more efficient degree of social-environmental actions into the local and regional scope.

However, when we analyze PES issues through a more critical point of view, there are authors who classified these PES initiatives as a geopolitical tool of maintenance of traditional oligarchies and regional groups of power influence, and also, the strength of the influence of the global market. Stripple apud Backstrand et. al. (2010) claims that there is a valorization of a pure technicism at the core of government environmental sectors worldwide. This author, researching the Clean Development Mechanism (CDM), the Carbon Market, the IPCC and the political actions of Kyoto Protocol, affirms that there is a "Weberian Climatic Policy". A Weberian Climate Policy means, in other way, that the idea of CDM comes firstly from powerful groups and sectors (that create the concepts and the rules), and only after this stage there is a valorization of the forms of governance (the valorization of the technical aspects that build the form of governance). This point of view can explain a critical view of the use of PES as a pure methodological tool of action without a substantial change into the philosophical scope of the government sectors.

There is another classical point of view which criticizes PES. For some researchers, PES is a pure market tool for the appropriation of the nature, conceptualizing all nature elements as products with a delimited price. This process of nature merchandizing is shown by Benton \& Short (1999), when the authors write about the environment history into the 1970's, 1980 's and 1990's. We should not forget the classical concepts of external and internal nature, presented by Smith (1984), who published a famous sociological and historical

proposes a convergence of information, communication and knowledge data, showing the territory into a space-territorial relation. This concept succeeds the concept of territoriality as a phenomenon of appropriation and re-appropriation of the natural resources which allows the presentation of the territorial project, where territorial level comes to develop".

8 According to Stripple apud Bäckstrand et. al. (2010), a "Weberian Climatic Police" is a "perspective on contemporary climatic police adopted; that rationalities of governance ultimately precede forms of governance" (p. 68). 
study about the dialectical Human $x$ Nature relation. Smith explained some aspects of the western concepts about the process of environment domination by Humankind (developing his concept of the Ideology of the Nature). These concepts strength a critical view of PES and of sustainable development as well.

This matter creates a dialectical issue about PES: PES, seen as an important tool for the development of environmental policies versus the idea that PES are useless without a deep reflection about its values and its concepts. This dialectical issue reminds the polemical theme about sustainable development.

However, there is a key aspect that we cannot forget when we discuss about PES: the environmental impacts from human activities are destroying the major ecosystems, and Humankind needs and explores more than the planet can regenerate (a similar opinion of Van Hacken et. al. (2015). There is an issue of time to adopt better choices and values for avoiding a possible future human collapse. We believe that Humankind does not have enough time to deal with such a deep change of social behavior about the planet management and itself. Because of this, Humankind is facing the challenge of developing actions and strategies like PES to achieve the main target of gaining time to have a better chance for developing values and their relationship with the planet. Finally, between PES, its technical aspects and reflection on Humankind versus Nature values, Connely \& Smith (1999) wrote that:

\footnotetext{
"Responsible environmental action requires serious reasoning about environmental issues. We need a clear grasp of the terms we use, the values we espouse, and our beliefs about what we consider it morally proper to do. Do we have responsibilities towards the environment? What might these responsibilities be? From what sources are they derived?

(...) Next, the relationship between environmental ethics is analyzed in order to situate the demand for a new, environmentally sensitive ethic. What possibilities and resources are offered by different philosophical approaches and traditions?
}

\section{EXAMINING THE OPPORTUNITY AND EFFICACY OF PAYMENT FOR ENVIRONMENTAL SERVICES IN BRAZIL}

Nowadays, it is a fact that environmental projects must be economically attractive, the main condition for many international organizations, such as the World Bank. For that, the protection of riparian areas in Brazil appears as an important opportunity for profits, which could become a type of win-win process. The win-win process is a desirable condition into PES proceedings, proceedings that value the concept of Economic 
Rationalism ${ }^{9}$ (Dryzek, 1997). Nevertheless, would a win-win condition be possible within PES proceedings in an extremely unequal society like the Brazilian?

The inequality between rich and poor classes would be maintained or even increased with PES actions, affecting the very meaning of PES win-win results between rich and poor classes. However, PES still are important tools of development and evolution within the scope of environmental policies and actions. Understanding and accepting this condition, there are in Brazil some examples of proceedings in preserving the riparian areas, as the River Basin Committee of Piracicaba-Capivari-Jundiai (PCJ). This group has a conception of creating systems of payment for the maintenance of that riparian area (Table 1). Table 1 shows an initiative of PCJ River Basin Committee in stipulating values of profits that would be paid to the land owner by his conserving efforts. This type of work is one of the pioneering acts with the main goal of paying for a PES in Brazil, but that action has not been fully implemented yet.

Table 1 - Hypothetical example of a land property with 100 hectares of preserved or conserved forest areas

Standard values of payment for the protection (conservation/preservation) of Areas of Permanent Preservation and other type of areas

Standard values of payment for the protection (conservation/ preservation) of Areas of Permanent Preservation only

$\%$ of recovered land property area

\begin{tabular}{|c|c|c|c|c|c|c|}
\hline & $\begin{array}{l}25 \text { to } \\
50 \%\end{array}$ & $\begin{array}{l}50 \text { to } \\
75 \%\end{array}$ & $>75 \%$ & Category & $\begin{array}{l}\text { Medium level } \\
\text { of quality of the } \\
\text { forest area }\end{array}$ & $\begin{array}{l}\text { High level of } \\
\text { quality of the } \\
\text { forest area }\end{array}$ \\
\hline $\begin{array}{c}\text { Value - High level of } \\
\text { preserv./ conserv. } \\
\text { forests }\end{array}$ & $42,00 \mathrm{BRL}$ & $\begin{array}{c}83,00 \\
\text { BRL }\end{array}$ & $\begin{array}{c}125,00 \\
\text { BRL }\end{array}$ & $\begin{array}{l}\text { Value (BRL/ha/year) in } \\
\text { new forest areas into the } \\
\text { land property }\end{array}$ & $83,50 \mathrm{BRL}$ & $125,00 \mathrm{BRL}$ \\
\hline $\begin{array}{c}\text { Value - Medium level } \\
\text { of preserv./ conserv. } \\
\text { forests }\end{array}$ & $25,00 \mathrm{BRL}$ & $\begin{array}{c}50,00 \\
\text { BRL }\end{array}$ & $\begin{array}{c}75,00 \\
\text { BRL }\end{array}$ & & & \\
\hline
\end{tabular}

Values presented by PCJ River Basin Committee - Brazilian State of Sao Paulo - Brazil (2006)

Below, we can see a trying for quantifying the values, in one year, considering the land endowed with high protected Areas of Permanent Preservation (1), Legal Forest Reserves Area (2) and Forest Bondage Area (3), in these hypothetical 100 hectares: [simulation presented by the authors]

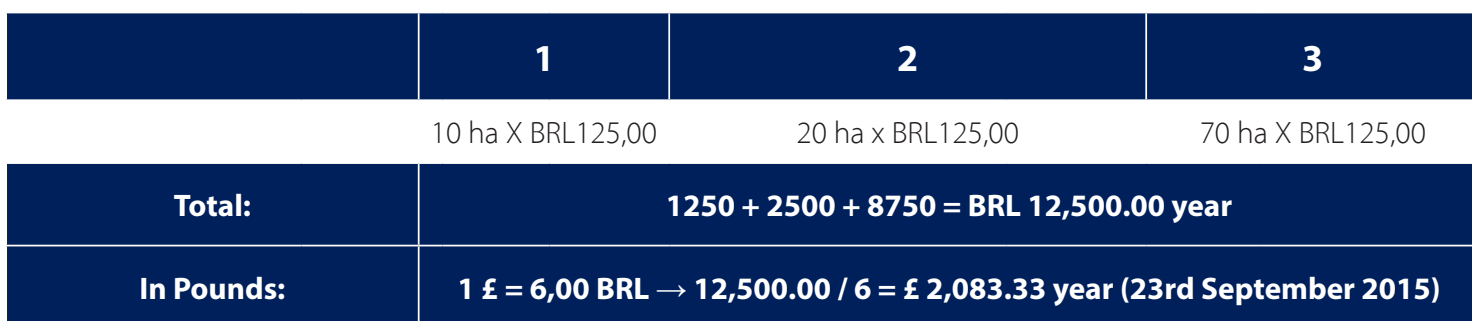

\footnotetext{
9 Quoting Dryzek (1997, p.102), the concept of Economic Rationalism may be defined by "its commitment to the intelligent deployment of market mechanisms to achieve public ends. It differs from administrative rationalism in its unremitting hostility to environmental management on part of government administrators".
} 
The main reason for showing the activities of the PCJ River Basin Committee is because that institution began the first initiatives in Brazil in which PES strategies were adopted for the development of these programs inside the Brazilian territory. Hence, this part of the paper focus on the PES possibilities based on what has worked for this Brazilian Water Committee. Also, we present a short model for the implementation of a PES in the following paragraphs.

The action of paying for preserving / conserving areas should include two other types of rural areas (as legal reserves and forest bondage) and not only the riparian areas or other permanent preservation areas. These three types of protected forest areas are classified by the Brazilian Forest Code (Law 12,651/2012). More than that, the land owners should earn not only because of the preservation and/or conservation of forest areas but also because of the period of time that these areas would be preserved or conserved too. Each year of conservation/preservation area would raise the currency earned up to a maximum limit of 21 years. There are really two major factors: preserved/conserved area in hectares and the period of time of preservation and conservation.

Conserving and/or preserving forest areas is not a fast action in every land ownership, if you consider the period of time it would take. In order to have a forest area in an advanced natural level of conservation/preservation, it may take more than three decades. However, the owners of properties which are conserving their areas should earn profits for that action and encourage other land owners to do the same. This sort of strategy could change eventually in the near future; a Brazilian traditional concept which considers that a forest area is not a profit space, searching to value the action of conserving/preserving green areas (Tables 1 to 4 ):

Table 2 shows the main characteristics of the Brazilian Environmental Services Act (PL 5487/2009), policy which has not been approved yet. This law structure presents three subprograms: the Brazilian Forests Subprogram, the Brazilian Water Provider Program, and the Brazilian Private Natural Heritage Reserve Subprogram. Each subprogram has its own rules and aspects (articles 7 to 9 of PL 5487/2009). We would draw attention to the fact that the most important type of subprogram, for the main goal of this article, is the Brazilian Water Provider Program. The Brazilian Environmental Services Act will create a Management Committee (article 14) to supervise the projects linked with these three subprograms and all the profits earned as well. Moreover, PL 5487/2009 will create a Brazilian Fund for Payment to Environmental Services (article 11 to 14) with the main reason of helping the Brazilian Environmental Services Act. 
Table 2 - Program of Environmental Services in Brazil
Project law 5487/2009
Intend to create the Brazilian Environmental Services Act
Intend to install the Brazilian Program of Environmental Services
(article 5) - include The Forests Subprogram;
(article 5) - include The Water Production Program, with special attention to article 9.

\section{Technical Sectors of the Watershed Committees}

\begin{tabular}{|c|c|c|}
\hline $\begin{array}{l}\text { Brazilian Bureau of Environment } \\
\text { and Renewable Natural Resources } \\
\text { (federal scale) }\end{array}$ & \multirow{2}{*}{$\$$} & $\begin{array}{l}\text { Brazilian Fund for payment to } \\
\text { Environmental Services (articles } \\
11 \text { to } 14 \text { ) }\end{array}$ \\
\hline $\begin{array}{l}\text { Legal Environmental Institutes of } \\
\text { each Brazilian State (state scale) }\end{array}$ & & $\begin{array}{l}\text { Management Committee } \\
\text { of Brazilian Program of } \\
\text { Environmental Services (article 14) }\end{array}$ \\
\hline & $\begin{array}{c}\text { WATER PRODUCTION } \\
\text { PROGRAM } \\
\text { Protector-receiver } \\
\text { concept }\end{array}$ & \\
\hline
\end{tabular}

Table 3 - Thinking about the possibilities of Water Provider Program

\begin{tabular}{|c|c|c|}
\hline \multicolumn{3}{|c|}{ [Purpose created by the authors] } \\
\hline $\begin{array}{l}\text { Areas of Permanent Preservation } \\
\text { (APP) } \\
\text { (Law 12.651/2012, Chapter Two) total } \\
\text { protection - payment for ha./year }\end{array}$ & $\begin{array}{l}\text { Legal Forest } \\
\text { Reserves Area } \\
\text { (Law 12.651/2012, } \\
\text { Chapter Four) } \\
\text { - conservation - } \\
\text { payment for ha./year }\end{array}$ & $\begin{array}{l}\text { Forest Bondage } \\
\text { total protection - payment ha./ } \\
\text { year }\end{array}$ \\
\hline \multicolumn{2}{|c|}{$\begin{array}{l}\text { Land property must be included at Brazilian Environmental- } \\
\text { Rural List (Law 12.651/2012, Chapter Six) }\end{array}$} & $\begin{array}{l}\text { Payment for Forest Bondage Area } \\
\text { cannot be effected if the area is a } \\
\text { leasing place which has a target of } \\
\text { environmental compensation for } \\
\text { other external land owners. }\end{array}$ \\
\hline $\begin{array}{l}\text { PROPERTY POSSIBILITIES } \\
\text { Possibility of inclusion of a } \\
\text { Agroforestry System at the property, } \\
\text { aggregating payment values to the } \\
\text { payment for environmental systems. } \\
\text { (the owner could earn with the land } \\
\text { products, with the carbon stocked } \\
\text { into the biomass and for ha./year of } \\
\text { certified conserved area. }\end{array}$ & $\begin{array}{l}\text { A Brazilian legal } \\
\text { environmental } \\
\text { bureau will be } \\
\text { in charge of the } \\
\text { analysis of possible } \\
\text { natural areas to the } \\
\text { payment amount. }\end{array}$ & $\begin{array}{l}\text { For a possible payment of } \\
\text { Environmental Services among } \\
\text { Water Provider Program: the } \\
\text { property must be georeferred } \\
\text { about its aspects considering land } \\
\text { use. The land owner must delimit its } \\
\text { Areas of Permanent Preservation, its } \\
\text { Legal Reserve Areas and its Forestry } \\
\text { Bondage Areas. }\end{array}$ \\
\hline
\end{tabular}


Table 4 - Thinking about the possibilities of Water Provider Program - II [Purpose created by the authors]

\begin{tabular}{|c|c|}
\hline $\begin{array}{l}\text { WATER PROVIDER PROGRAM } \\
\text { Protector-receiver concept }\end{array}$ & $\begin{array}{l}\text { Main target: the land owner will protect the } \\
\text { water resources and soils of his/her property } \\
\text { if he/she is financially stimulated by the } \\
\text { government environment system. }\end{array}$ \\
\hline $\begin{array}{l}\text { This program, in the future, could help to } \\
\text { create a better form of payment process for } \\
\text { the protection of APP areas (hectare/year), } \\
\text { for the protection of Legal Forest Reserves } \\
\text { (hectare/year) and for the protection of Forest } \\
\text { Bondage areas. }\end{array}$ & $\begin{array}{l}\text { The payment for the preserved or conserved } \\
\text { hectare/year will depends on the size of the } \\
\text { protected area, and it will be multiplied by } \\
\text { the time/period that area is protected, with a } \\
\text { maximum value of money that can be earned } \\
\text { for the land owner after } 20 \text { years. }\end{array}$ \\
\hline
\end{tabular}

The protection level of this area will be analyzed by the Brazilian State Institute in charge or by the Technical Group of Local River Basin Committee Area.

\section{About the use of Universal Soil Loss Equation (USLE)}

\section{$A=\operatorname{RKLSCP}$}

$A=$ Soil loss by erosion - ton/ha.year;

$\mathrm{R}=$ Rain erosion factor - Mj.mm/ha.h.year;

$\mathrm{K}=$ Soil erosion factor - ton.h/Mj/mm/year;

$L=$ Slope length factor (non-dimensional);

$\mathrm{S}=$ Gradient terrain slope factor (non-

dimensional);

$C=$ Soil Land Use factor (non-dimensional);

$\mathrm{P}=$ Experiences in land conservation factor

(non-dimensional);

It is important to show that there are three ways for classifying the protected forests areas in rural lands by the Brazilian Forest Code. There are two types of forest areas to preserve (Areas of Permanent Preservation and Forest Bondage Areas), and one area with a main goal of conservation (Legal Forest Reserves Area). The preservation areas have stricter scopes of action, mainly because of the fact that the land owner would earn profits only with the preservation of the land. The Legal Forest Reserve Area has a more complex scope of business action, because the possibility of profits with a possible inclusion of an Agroforestry System. According to any Agroforestry System, there is a traditional aspect which allows this kind of system to be assimilated by the carbon market. That possibility could give conditions to the land owners to earn profits with the fixation of carbon in their conserved area. In any case, the property must be included on the Brazilian Environmental-Rural List (this inclusion is a legal obligation of the land owner into Brazilian Forest Code rules). 
Thinking about this system of PES, a main question arises: would the land owner follow policy signals and adopt conservation practices? In order to answer this question, it is necessary to follow two pathways: the first one, according to the Brazilian Forest Code, is that the land owner must preserve the Areas of Permanent Preservation and Forest Bondage Areas and must conserve his Legal Forest Reserves Area. The second is quantifying how profitable this system can be to stimulate this action, highlighting the principle of protector-receiver.

This system only can be functional if the properties are correctly georeferred inside an organized data bank (this data bank is being developed within the Brazilian Environmental-Rural List System (Law 12.651/2012). This data will show the vast sectors of the properties that must be protected. The execution of that geo-spaciousness work would be done by the respective Brazilian River Basin Committee. Nevertheless, the mission of watching if these areas are really conserved and preserved would be done by the respective public environmental institute (this environmental institute could be a state one). This environmental institute should work with a River Basin Committee together.

The fund that would feed this PES system would be provided by the Brazilian Environmental Ministry every year with the supervision of the Management Committee of Brazilian Environmental Services Act (see Figure 2). This Ministry would allocate the money to each Brazilian state into a proportion (as a percentage) which regards the economic strength of the respective state (quantifying, for example, the state GDP) and also considering the number of the respective state river basin committees. The state institute which would receive that fund is the respective State Hydric Resource Council and that fund would not be applied for any other purposes. Whenever each State Council receives its respective fund, it should pass the amount to the respective River Basin Committee in the right proportion, and that committee would be responsible for the correct process of the land owner payment. The payment would be made to the land owner once a year.

Taking into account that Brazil has 329,971,728 million hectares (estimated by IBGE, 2006) and 68.73\% is used for commercial purposes, this means that in Brazil 226,789,568.65 hectares are used for commercial purposes. If we suppose that each land owner would earn BRL 100,00 per hectare, this PES system would cost the Brazilian Treasure an amount of 4.53 billion BRL per year (approx. 750 million GBP), if we consider only $20 \%$ of Legal Forest Reserve Area in each property. However, we are not quantifying here the Areas of Permanent Preservation and/or the Forest Bondage Area, not even the Brazilian territory of Legal Amazon (the Legal Amazon Region has different percentages of conservation/ preservation within the Law 12,651/2012). 
Figure 1 - Thinking about a PES structural system in a national scale for Brazil (created by the authors).

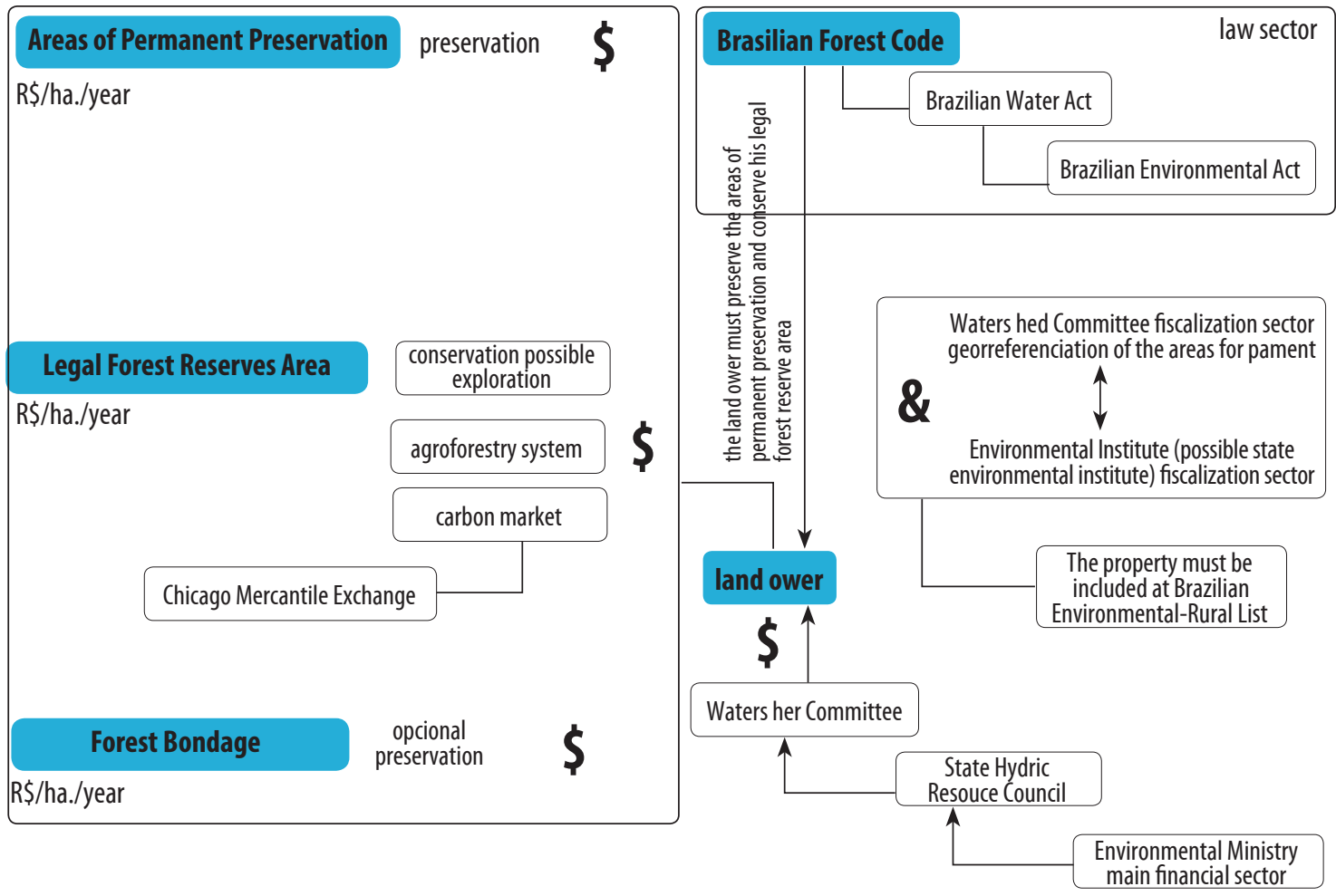

\section{CONCLUSIONS}

Following the explanations above, we can summarize this paper into three main topics:

1. the undeniable importance of the environmental actions based on economic concepts (PES). It means that the discussion about PES could become more prominent if the economic and political concepts were connected to the construction of environmental actions. More than that, the development of a better payment system for environmental services could be a fundamental step in the right direction and towards sustainable development, if we consider that the discourse of the sustainable development claims for a new, modern and more technical system of environmental actions. In that way, the creation of a system of PES strengthens and values the existence of forest areas, water sources, fertile soils and landscapes as well. Then, the principle of the protector-receiver cannot be ignored because it has a high potential for the environmental improvement. The financial attraction may boost social actions and common obedience to the laws, however, it must be said that the laws and legal rules will always exist and, thus, everyone must respect them, regardless whether these would be financially rewarding. 
2. About Brazil, our study area, this important nation should develop PES actions searching for a significant rise of its environment policy, increasing the level of Brazilian people quality of life and State Government stability. It is a historic fact that the Brazilian economic base is formed by its strong commodities trade. Because of that, the success of its environment policy is in effect a matter of State and if Brazilian Environmental policy is not successful, this country could suffer an economic, an environment and a social future knockdown. If the Amazon and Brazilian Savanna biomas are not better managed, these landscapes will be severely impacted, influencing the entire Brazilian economy and eventually society. Also, this serious situation could affect directly other neighbor South American countries as well. More than that, a possible future Brazilian knockdown could impact the entire global market in its ever growing need for primary products. For these reasons, PES are a strategic and fundamental tools for Brazil, for their policy development and for more intelligent and rational scope of actions in its territory.

3. This paper emphasizes the issue of time that Humankind has to change its own actions towards the planet and its resources. This is a common fact into the academic sectors that Humankind is exploring the planet resources much faster than Earth can regenerate, creating conditions for a likely future collapsing scenario. Following this ratio, PES actions could be used for the security of society because these actions could provide more time for people and countries to develop even better strategical social, economic and environmental actions. Anyway, this tool must be used for a deeper and better reformulation of values and concepts within the economic, politic and social global scopes.

\section{ACKNOWLEDGEMENTS}

Andre Geraldo Berezuk would like to express his gratitude to Laboratory of Physical Geography of Federal University of Grande Dourados - Brazil, because of the material support, in special for Professor Charlei Aparecido da Silva.

This work was supported by the Brazilian Council for Scientific and Technological Development (CNPq) under Grant number 200805/2015-0. 


\section{REFERENCES}

1. AB'SABER, A. N. Elements for a strategy for terrestrial settlement and ecodevelopment in the Amazon apud CLÜSENER-GODT, M. \& SACHS, I. Brazilian perspectives on sustainable development of the Amazon region. UNESCO, Man \& the Biosphere Series, v. 15, 1995. pp. 287-311.

2. AGORAMOORTHY, G.; HSU, M. J.; SHIEH, P. India's women-led vegetable cultivation improves economic and environmental sustainability. Scottish Geographical Journal, Routledge, Vol. 128, No. 2, 87-99, June 2012.

3. AGUSTSSON, K.; GARIBJANA, A.; ROJAS, E.; VATN, A. An assessment of the Forest Allowance Programme in the Juma Sustainable Development Reserve in Brazil. International Forestry Review, 16(1):87-102, 2014.

4. BARNES, P. M.; BARNES, I. G. Environmental policy in the European Union. Cheltenham : Edward Elgar, 1999. 344 p.

5. BECKER, B. Undoing myths: the amazon: an urbanized forest. apud CLÜSENER-GODT, M. \& SACHS, I. Brazilian perspectives on sustainable development of the Amazon region. UNESCO, Man \& the Biosphere Series, v. 15, 1995. pp. 53-90.

6. BENTON, L. M.; SHORT, J. R. Environmental discourse and practice. Oxford : Blackwell, 1999. $219 \mathrm{p}$.

7. BERTACCHINI, Y. Intelligence territoriale. Le Territoire dans tous ses 'etats. ISBN : 2-95193201-4 EAN : 9782951932012. Collection Les ETIC, Presses Technologiques, Toulon., pp.316, 2007. $<$ sic 00186775>

8. BRAZIER, V.; BRUNEAU, P. M. C.; GORDON, J. E.; RENNIE, A. F. Making space for Nature in Changing Climate: the role of geodiversity in biodiversity conservation. Scottish Geographical Journal, Routledge, Vol. 128, Nos. 3-4, 211-233, September-December 2012.

9. BRAZIL. Project Law 5487/2009 - Environmental Services Project Law - Allowed in <http://www.camara.gov.br/proposicoesWeb/prop_ mostrarintegra;jsessionid=C77F18EE283CFB1D256DC5B 1 F 3 A 30167. node2 ? codteor $=667325 \&$ filename $=\mathrm{PL}+5487 / 2009>$

10. . Law 9433/1997, Brazilian Water Law. Allowed in <http://www.planalto.gov.br/ ccivil_03/leis/L9433.HTM>

11. Law 6938/1981, Brazilian Environmental Law. Allowed in <http://www.planalto. gov.br/ccivil_03/leis/16938.htm>

12. L L . Law 7804/1989. Major changes in Brazilian Environmental Law and creation of IBAMA. Allowed in <http://www.planalto.gov.br/ccivil_03/Leis/L7804.htm>

13. . Law 9984/2000. Creation of the Brazilian Water Agency - ANA. Allowed in <http:// www.planalto.gov.br/Ccivil_03/Leis/L9984.htm>

14. L_L Law 11516/2007. Creation of Chico Mendes Biodiversity Institute - ICMBio. Allowed in <http://www.planalto.gov.br/ccivil_03/_ato2007-2010/2007/lei/l11516.htm> 
15. . Law 12.651/2012, Brazilian Forest Code. Allowed in <http://www.planalto.gov.br/ ccivil_03/_ato2011-2014/2012/lei/L12651compilado.htm>

16. Decree 4297/2002, Ecological-Economic Zoning Rules. Allowed in <http://www. planalto.gov.br/ccivil_03/decreto/2002/D4297.htm>

17. BRAZILIAN CONSTITUTION. Allowed in <http://www.senado.gov.br/legislacao/const/ con1988/CON1988_04.02.2010/CON1988.pdf>

18. BRAZILIAN WATER AGENCY. Water provider program. Allowed in $<$ http://produtordeagua. ana.gov.br//>

19. BROWN, C.; McMORRAN, R.; PRICE, M. F. Rewilding - a new paradigm for Nature Conservation in Scotland? Scottish Geographical Journal, Routledge, Vol. 127, No. 4, 288 314, December 2011.

20. BUSCHER, B. Selling Success: Constructing Value in Conservation and Development. World Development, 57, 79-90, 2014. http://dx.doi.org/10.1016/j.worlddev.2013.11.014

21. CANEPA, E. M.; PEREIRA, J. S.; LANNA, A. E. L. A política de recursos hídricos e o princípio usuário pagador (PUP). Porto Alegre: Revista Brasileira de Recursos Hídricos, n.1, 103-117, jan-mar.1999.

22. CONNELLY, J.; SMITH, G. Politics and the environment: from theory to practice. London : Routledge, 1999. $340 \mathrm{p}$.

23. CLÜSENER-GODT, M. \& SACHS, I. Brazilian prspectives on sustainable development of the Amazon region. UNESCO, Man \& the Biosphere Series, v. 15, 1995.

24. DRYZEK, J. S. The politics of the earth: environmental discourses. New York : Oxford, 1997. $220 \mathrm{p}$.

25. FEARNSIDE, P. M. Agroforestry in Brazil's amazonian development policy: the role and limits of a potencial use for degraded lands apud CLÜSENER-GODT, M. \& SACHS, I. Brazilian perspectives on sustainable development of the Amazon region. UNESCO, Man \& the Biosphere Series, v. 15, 1995. pp. 125-148.

26. HIDROWEB. Agência Nacional das Águas - WATER RESOURCES MANAGEMENT IN BRAZIL - Brazilian Government - http://hidroweb.ana.gov.br/cd2/water/docs/part2.htm

27. LOURENÇO, J. S. Organizing research for the development of the Amazon region: in Brazil and among the signatory countries of the Amazonian co-operation treaty In: CLÜSENERGODT, M. \& SACHS, I. Brazilian perspectives on sustainable development of the Amazon region. UNESCO, Man \& the Biosphere Series, v. 15, 1995. pp. 237-257.

28. ELOY, L.; COUDEL, E.; TONI, F. Implementando pagamentos por serviços ambientais no Brasil: caminhos para uma reflexão crítica. Sustentabilidade em Debate, 4(1):21-42, 2013.

29. FISHER, J. A.; PATENAUDE, G.; GIRI, K.; LEWIS. K.; MEIR, P.; PINHO, P.; ROUNSEVELL, M. D. A.; WILLIANS, M. Understanding the relationship between ecosystem services and poverty alleviation: a conceptual framework. Ecosystem services, 7:34-45, 2014. 
30. FUKUYAMA, F. Construção de estados. Rocco, 1 ed., 168, 2005.

31. HANSOM, J. Geodiversity in a Changing Environment. Scottish Geographical Journal, Routledge, Vol. 128, Nos. 3-4, 173-176, September-December 2012.

32. INSTITUTO BRASILEIRO DE GEOGRAFIA E ESTATÍSTICA. Censo Agropecuário 2006. Allowed in: <http://www.ibge.gov.br>. Access in: 14 jul. 2014.

33. IORIS, A.A. R. Passado e presente da Política de Gestão de Recursos Hídricos no Brasil. Lisbon, Finisterra, year 41, number 82, 2006. pp. 87-99.

34. The political nexus between Water and Economics in Brazil: a critique of recent policy reforms. Review of Radical Political Economics, 42 (2), 231-250, 2010.

35. LANNA, A. E. L.; PEREIRA, J. S.; HUBERT. G. Os novos instrumentos de planejamento do sistema francês de gestão de recursos hídricos: II - reflexões e propostas para o Brasil. Porto Alegre: Revista Brasileira de Recursos Hídricos, 7 (2), 81-107, 2002.

36. LUCHINI, A. M. Os desafios à implementação do sistema de gestão de recursos hídricos estabelecido pela 9433/97. Rio de Janeiro: Revista de Administração Pública, 34 (1), 123-143, jan-mar.2000.

37. NEDER, R. T. Crise socioambiental: Estado \& sociedade civil no Brasil (1982-1998). São Paulo : Annablume, FAPESP, 2002. $438 \mathrm{p}$.

38. SAO PAULO STATE - BRAZIL. State Law 7663/1991, Sao Paulo State Water Law. Allowed in $<$ http://www.al.sp.gov.br/repositorio/legislacao/lei/1991/lei-7663-30.12.1991.html> - Access in: 01 jul. 2014.

39. SETTI, A.A. et. al. Introdução ao gerenciamento de recursos hídricos. Brasília: ANEEL, Superintendência de Estudos e Informações Hidrológicas, 2. ed., 2001. 207 p.

40. SMITH, N. Uneven development: capital, nature and the production of space. Oxford: Blackwell, 1984. 198 p.

41. STRIPPLE, J. Weberian climate policy: administrative rationality organized as a market. In: BÄCKSTRAND, K. et. al. Environmental politics and deliberative democracy: examining the promise of new modes of governance. Cheltenham: Edward Elgar, 2010. pp. 67-84.

42. VAN HACKEN, G.; BASTIAENSEN, J.; WINDEY, C. The frontiers of the debate on Payments for Ecosystem Services. A proposal for innovative future research. Antwerp - Belgium: Institute of development policy and management, University of Antwerp, aug. 2015. 52 p.

43. VEIGA, L. B.E.; MAGRINI, A. The Brazilian Water Resources Management Policy: Fifteen Years of Success and Challenges. Water Resource Management (2013) 27: 2287-2302 DOI 10.1007/s11269-013-0288-1.

44. WUNDER, S. Payments for environmental services: some nuts and bolts., Bogor, Indonesia: CIFOR Occasional Paper No. 42. Center for International Forestry Research, 2005. 26p.

Artigo recebido em 25 de fevereiro de 2016.

Artigo aceito em 20 de março de 2016 